\title{
Rompalina
}

(8)

\section{An "extra-vagant" scholar}

\author{
Autor(es): $\quad$ McIntosh, James
}

Publicado por: Imprensa da Universidade de Coimbra

URL

persistente: URI:http://hdl.handle.net/10316.2/42370

DOI: $\quad$ DOI:https://doi.org./10.14195/978-989-26-1308-6_54

Accessed : $\quad$ 26-Apr-2023 14:50:36

A navegação consulta e descarregamento dos títulos inseridos nas Bibliotecas Digitais UC Digitalis, UC Pombalina e UC Impactum, pressupõem a aceitação plena e sem reservas dos Termos e Condições de Uso destas Bibliotecas Digitais, disponíveis em https://digitalis.uc.pt/pt-pt/termos.

Conforme exposto nos referidos Termos e Condições de Uso, o descarregamento de títulos de acesso restrito requer uma licença válida de autorização devendo o utilizador aceder ao(s) documento(s) a partir de um endereço de IP da instituição detentora da supramencionada licença.

Ao utilizador é apenas permitido o descarregamento para uso pessoal, pelo que o emprego do(s) título(s) descarregado(s) para outro fim, designadamente comercial, carece de autorização do respetivo autor ou editor da obra.

Na medida em que todas as obras da UC Digitalis se encontram protegidas pelo Código do Direito de Autor e Direitos Conexos e demais legislação aplicável, toda a cópia, parcial ou total, deste documento, nos casos em que é legalmente admitida, deverá conter ou fazer-se acompanhar por este aviso.

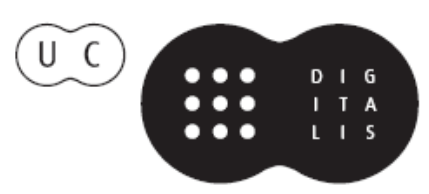





\section{A N"EXTRA - VA GANT" SCHOLAR}

James McIntosh

I first knew Maria Irene Ramalho Santos as a student in a two-semester graduate survey of American literature I taught at Yale some forty-seven years ago. She came to the class with a thorough background in English and European literatures, but without much familiarity with American literature, a renegade and upstart field of inquiry even in the United States at that time. Thus in her choice of fields she already showed her adventurous spirit. She was more mature and wiser than most members of the seminar. She brought not only a cosmopolitan perspective but also a tenacious moral imagination to our discussions. I continued to take an interest in her work during her years at Yale and we have shared our writings and our intellectual concerns ever since.

Professor Ramalho Santos is in her own terms an "extra-vagant" scholar, with the Thoreauvian capacity to wander beyond ordinary disciplinary and cultural boundaries. She is not only one of the leading European scholars of American literature, but also a key figure in the American Studies movement internationally. Daringly and extra-vagantly, she has been an advocate for poetry and the Humanities within American Studies, while remaining open to the continually self-transforming democratic character of the movement. Her focus on comparative poetics, the defense and exposition of 
poetry in an international cultural context, is exemplary and virtually unique in American Studies. In her critical writing her views are vigorously independent, while informed by her wide knowledge of different national literatures and critical traditions. Her independence, however, is balanced by a generosity of spirit. Her gratitude for her learning is evident in all her writings.

I experienced Professor Ramalho Santos's energetic generosity when she invited me to give a lecture and conduct a seminar at Coimbra in May, 2001. She organized my visit thoughtfully and efficiently, welcomed me effusively, and made the whole series of events one of the most rewarding experiences in my career. It was clear to me also that she had developed an extraordinary center for the study of American literature and especially poetry at Coimbra, one of the liveliest and most engaged community of scholars and readers I have ever observed. I am extremely grateful to her for her hospitality then and for her intellectual friendship throughout my career. I am not alone in my gratitude. Her hospitality and generosity to poets and scholars from many places have helped to foster a world community in the Humanities, with a center at Coimbra. 